\title{
Using a social-ecological systems perspective to understand tourism and landscape interactions in coastal areas
}

\author{
Jasper Hessel Heslinga, Peter Groote and Frank Vanclay
}

\begin{abstract}
Purpose - The purpose of this paper is to look at the potential synergies between tourism and landscapes and examine the potential contribution of tourism to build social-ecological resilience in the Dutch Wadden. Design/methodology/approach - The authors reveal how a social-ecological systems perspective can be used to conceptualize the Wadden as a coupled and dynamic system. This paper is a conceptual analysis that applies this approach to the Dutch Wadden. The data used for the inquiry primarily comes from a literature review.

Findings - The authors argue that the social-ecological systems perspective is a useful approach and could be used to improve the governance of multi-functional socio-ecological systems in coastal areas. Opportunities for synergies between tourism and landscapes have been overlooked. The authors consider that tourism and nature protection are potentially compatible and that the synergies should be identified.

Research limitations/implications - This paper is only a conceptual application rather than an empirical case study. Further research to actually apply the methodology is needed.

Practical implications - Managers of protected areas should consider applying a social-ecological systems approach.

Social implications - The views of a wide variety of stakeholders should be considered in landscape planning.

Originality/value - The value of this paper lies in the articulation of the social-ecological systems perspective as a way to identify and understand the complex interactions between tourism and landscape, and the potential synergies between them.
\end{abstract}

Keywords Resilience, Ecosystem services, Integrated coastal zone management, Landscape management, Multi-functionality, Tourism studies

Paper type Research paper

\section{Introduction}

As in many coastal areas worldwide, the Dutch Wadden is experiencing an increase in socio-economic pressures on its ecosystems as a result of human activities such as agriculture, fishing, human settlement, manufacturing, resource extraction, shipping and tourism (Kabat et al., 2012). All these activities have impacts on the natural environment, albeit in various ways. Tourism has mutual relationships and interdependencies with the landscape (Terkenli, 2004). It is an example of a socio-economic activity that is normally considered to have negative impacts on the landscape (Buckley, 2012; Saarinen, 2006) and on host communities (King et al., 1993; McCombes et al., 2015). Conversely, tourism benefits from an attractive landscape and natural environment and a welcoming host community (Buckley, 2011). Tourism is often seen as a means to provide income and jobs to the local community (Libosada, 2009). However, tourism is more than just an economic industry (Higgins-Desbiolles, 2006) since it can also be an opportunity for improving the understanding of natural heritage, for gaining public support, and to achieve the funding needed for conservation (Libosada, 2009; McCool and Spenceley, 2014). Therefore, tourism is highly dependent on the qualities of the
Jasper Hessel Heslinga and Peter Groote are both based at the Department of Cultural Geography, University of Groningen, Groningen, The Netherlands. Frank Vanclay is a Professor of Cultural Geography at the Department of Cultural Geography, University of Groningen, Groningen, The Netherlands.
Received 21 October 2015 Revised 11 April 2016 12 May 2016 Accepted 9 July 2016

C Jasper Hessel Heslinga, Peter Groote and Frank Vanclay. Published in the Journal of Tourism Futures. This article is published under the Creative Commons Attribution (CC BY 4.0) licence. Anyone may reproduce, distribute, translate and create derivative works of this article (for both commercial and noncommercial purposes), subject to full attribution to the original publication and authors. The full terms of this licence may be seen at http://creativecommons.org/ licences/by/4.0/legalcode

This work is part of the research programme which is financed by the Province of Fryslân and the Wadden Academy. 
landscape to remain attractive to tourists (Liu et al., 2007). Because of tourism's mutual relationship with the landscape, tourism can be seen as an opportunity to increase an area's social-ecological resilience, as it could provide a balance between the sometimes competing goals of maintaining the natural qualities of the area and attaining socio-economic benefits. To achieve both goals, it is important that the synergistic interactions between tourism and landscape are recognized and stimulated. In this paper, synergies are defined as being potentialities to achieve greater combined outcomes across the range of social and ecological dimensions (Persha et al., 2011).

With increasing rates of tourism, the impact of tourism is expected to increase in the future (UNWTO, 2010). Therefore, finding synergies between tourism and landscape becomes particularly important. Worldwide, tourism has been undergoing expansion and diversification over the last six decades and is one of the largest and fastest growing economic sectors in the world (UNWTO, 2010). There are many types of tourism that interact differently with nature and landscape (Williams, 2009). The impacts on the landscape and on communities and the way interactions are managed may vary significantly. In this paper, we focus on those forms of tourism which require landscape qualities, e.g., nature tourism, ecotourism and sustainable tourism. As these have grown relatively fast, the pressure of tourism on the natural environment is increasing and this has consequences which may change both the landscape and the way tourism interacts with it (Newsome et al., 2013). This implies that when an increase in tourism negatively impacts the landscape, this may also have negative consequences for tourism. The combination of the increase in human impacts on the natural environment due to socio-economic activities and the expansion of tourism as a growing economic sector inevitably leads to conflicting interests. To serve the needs of both protection of nature and socio-economic development, it is important to find synergies between tourism and landscapes.

Establishing synergies between tourism and the landscape is difficult because opportunities for synergies are often overlooked. It is commonly known that, despite huge social impact on the community, tourism could provide economic opportunities and may enhance the quality of life for both residents and tourists (Goodwin, 2011; McCool and Spenceley, 2014; McCombes et al., 2015). However, an emphasis solely on the socio-economic benefits of tourism may be ecologically undesirable, as ecological qualities are under stress due to overexploitation of the natural resources by tourism. Conversely, a coastal area that is strongly protected and viewed as an ecological island without human influence could be socially undesirable (Adger, 2000). The challenge is to find the right balance between nature protection and socio-economic development.

To find this balance, it is important to look at the interactions between society and nature (Cumming, 2011a). However, there is a lack of research focussing specifically on understanding the interactions between tourism and landscapes (Gkoltsiou and Terkenli, 2012). To understand these interactions better, this paper argues that a social-ecological systems perspective would be useful. Such a perspective sees tourism and landscapes as being part of an integrated system, rather than as being separate entities (Farrell and Twining-Ward, 2004; Kirchhoff et al., 2010; Levin et al., 2012). This perspective could be used to critically examine past and contemporary planning institutions, policies and processes, which have typically seen nature and human activities as being functionally distinct. In the past, tourism was mainly seen as an engine for regional economic growth (Higgins-Desbiolles, 2006), and the natural environment was set aside as an "ecological island" to maintain a natural state with minimal human interference (Cumming et al., 2015).

A social-ecological systems perspective provides a dynamic approach. Tourism and landscape cannot be understood by only thinking in terms of stability and certainty. Instead, social-ecological systems thinking can contribute to tourism in nature areas as a way of dealing with change and uncertainty. Thus, using a social-ecological systems perspective has implications for the way "tourism and landscape" is managed. Therefore, this paper explains what this perspective means for the governance of tourism and landscape, and the role that institutions play.

This paper is structured around three arguments. First, a social-ecological systems perspective is presented to understand the interactions between tourism and landscape in coastal areas better. This perspective can be helpful in seeing tourism and coastal areas not as separate entities, 
but as a coupled and integrated whole. Second, a social-ecological systems perspective is also characterized as a dynamic perspective, which may help to understand changes in tourism and landscape better. Third, this paper explores the implications for the planning and governance of tourism and landscape from a social-ecological systems perspective. It is a conceptual paper that uses the Dutch Wadden as an illustrative example to demonstrate the effectiveness of the social-ecological systems perspective.

\section{Tourism and coastal areas as components of social-ecological systems}

This paper explores the potential use of the social-ecological systems perspective to consider tourism in natural coastal areas. This perspective has only recently gained importance in tourism planning, and definitions are continuing to evolve (Binder et al., 2013). We follow the general definition given by Berkes (2007) and Folke et al. (2010) who consider that a social-ecological system is an integrated system of ecosystems and human societies with interdependencies and reciprocal feedback loops. By highlighting the two basic characteristics of social-ecological systems (discussed below), this paper assists in bringing about a greater understanding of tourism and landscapes. The first characteristic is that tourism and landscape are part of a coupled system. The second is that resilience is a fundamental part of social-ecological systems. Resilience incorporates dynamics and change, and allows for that fact that both tourism and landscape are constantly changing.

\subsection{Components of a coupled system}

Several researchers have been asking for a systems perspective that enables the integration of social and natural systems in tourism (Parra, 2010; Halliday and Glaser, 2011; Ruiz-Ballesteros, 2011). They emphasize that social and natural systems mutually influence each other and a focus on the complex interrelations between tourism and landscape can provide a better understanding of the whole system. Terkenli (2004) argues that the understanding of these complex interrelationships is largely unexplored. Tourism and landscapes have often been seen as separated from each other (Stoffelen and Vanneste, 2015). As an alternative to the traditional, reductionist perspective that sees society and nature as separate entities that are predictable and controllable (Armitage et al., 2009; Plummer and Fennell, 2009), the social-ecological systems perspective does not see nature and society as separate, but rather as an integrated whole (Amérigo et al., 2007; Cumming, 2011b; Levin et al., 2012). Instead of predictability and controllability, the social-ecological systems perspective accepts that nature is inherently unpredictable, and that systems are complex and dynamic (Berkes et al., 2003).

Managing tourism and landscape in a more integrated way is not an entirely new idea. Earlier attempts such as integrated coastal zone management (ICZM) also argued for integration, but Shipman and Stojanovic (2007) criticized ICZM for its "democratic deficit", as it failed to include community engagement sufficiently. Ecosystem services also entails human-nature relations (Costanza and Farley, 2007) by focussing on the benefits of ecosystems to humans (Millennium Ecosystems Assessment, 2005). However, the concept of ecosystem services is accused of being too anthropocentric and of promoting the exploitation and commodification of nature (Schroter et al., 2014; Robertson, 2012).

The social-ecological systems perspective considers that the distinction between the social and natural systems is artificial and therefore both ecological and social research have to consider human and ecological components (Liu et al., 2007). Traditionally, ecological research often excluded humans from the system, while social research tended to ignore the ecological consequences of human action (Berkes, 2007; Folke et al., 2005). This blinkered vision was also evident in traditional research on tourism in coastal areas. On the one hand, tourism was seen from an economic perspective, i.e., as a driver of regional economic growth and as an industry, which, through visitor spending, increased job opportunities and tax revenues and enhanced a community's overall economic base (Hall and Page, 2006). This research failed to consider the environmental impacts of tourism and consequently failed to understand the landscape-tourism nexus (Hall and Page, 2006; Buckley, 2011). On the other hand, the natural environment where tourism takes place was often seen as an ecological island where nature was kept aside in a 
frozen steady state from which humans should be excluded (Shultis and Way, 2006; Cumming et al., 2015). The consequence of this non-anthropocentric view of protection is that nature and non-nature areas are spatially and functionally separated from each other.

Due to the separation between nature protection and socio-economic development, opportunities for synergies between tourism and landscapes have been overlooked. This is because tourism does not fit a mono-functional model with a focus on only one type of land use. Instead, tourism should be seen from a multi-functional position where tourism is embedded with other functions in an area (Hartman and de Roo, 2009). Figure 1 visually represents this idea of the separation or integration of functions. The traditional mono-functional positionings are in the upper left and lower right quadrants and represent a focus exclusively on either nature protection or socio-economic development. For a more multi-functional positioning, it can be interesting to explore the other two quadrants. These are the quadrants where tourism has the potential to connect to both nature protection and socio-economic development. The arrows in Figure 1 indicate the desirable shifts towards either protection by grasping use opportunities that are compatible with nature; or towards socio-economic development that takes appropriate risk-avoidance. Using a social-ecological systems perspective is likely to reveal the factors that link the natural and human components of the system. Such a perspective can help strive for a balance between nature protection and socio-economic development and improve policies that promote synergies between them.

\subsection{Resilience as a dynamic characteristic of a social-ecological system}

Next to a coupled system, the social-ecological systems perspective is also characterized as a dynamic perspective on tourism and landscapes that can deal with change and uncertainty. To understand tourism and landscapes as complex social-ecological systems that are continually adapting to changing circumstances (Strickland-Munro et al., 2010), the concept of resilience needs to be discussed. Resilience thinking has emerged as a conceptual framework that can help to understand change and the multiple, cross-scale interactions in social-ecological systems (Plummer and Armitage, 2007). Although resilience is potentially a property of all systems, according to Plieninger and Bieling (2012), the concept of resilience is particularly appropriate to social-ecological systems because both concepts are on the interface of human and natural processes in time and space, and share an interest in the protection, management and planning of areas. Walker et al. (2004) state that resilience is an attribute of a social-ecological system and it determines the ability of a social-ecological system to adapt to and benefit from change. In that sense, resilience is at the core of what drives social-ecological systems (Folke et al., 2010).

\section{Figure 1 Finding synergies between tourism and landscape}

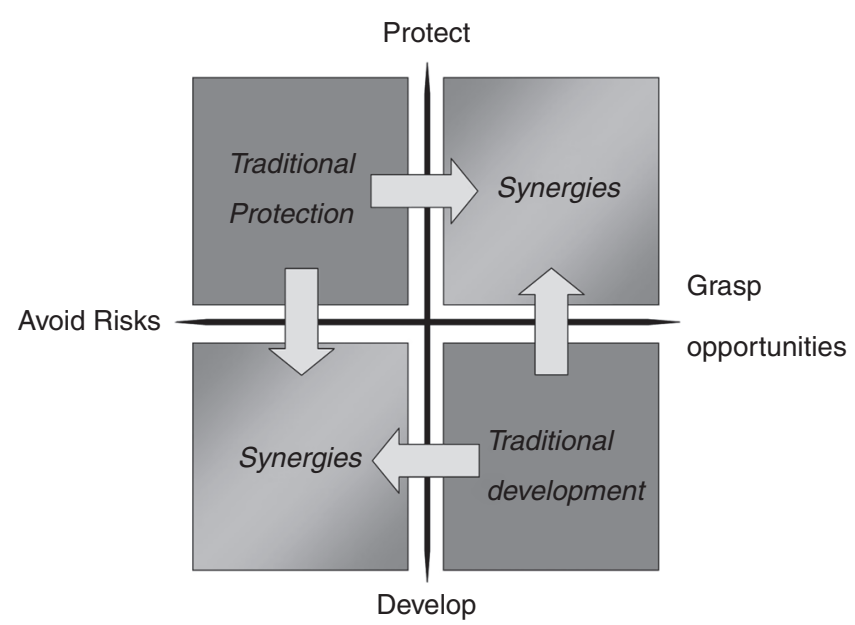

Source: Author, adapted from Hartman et al. (2011) 
The use of the concept of resilience to study the complex interactions between tourism and landscapes is relatively new (Becken, 2013). However, resilience has gained importance in the field of ecology (Holling, 2000), and the term has been used in a wide variety of works regarding interactions between people and nature (Carpenter et al., 2001). Many scholars use resilience in issues related to ecosystems (Gunderson et al., 2006), flooding (Adger et al., 2005), climate change (Davoudi, 2012), or risk and disaster management (Cox and Perry, 2011). Despite the dynamic nature and relative unpredictability of tourism (Schianetz and Kavanagh, 2008), and thus the potential value of resilience to tourism, little research has been done to adapt tourism management tools to take uncertainty and unexpected changes into account (Luthe and Wyss, 2014).

In this paper, resilience can help to understand the dynamics between tourism and landscapes. Understanding changes between them can help policy makers respond better to these changes. This is important for finding synergies between tourism and landscape as this requires balance between nature conservation and socio-economic development. Plieninger and Bieling (2012) argue that linking resilience thinking to landscapes can contribute to this balance since this linkage may help in creating a deeper understanding of the causes and consequences of landscape changes and the strategies that exist for managing these changes. Nevertheless, using resilience to understand the dynamics in the interactions between tourism and landscape is still relatively uncommon.

The literature on resilience contains a multitude of viewpoints, and an overview is presented in Table I. We adhere to the social-ecological (or evolutionary) view of resilience, which rejects the idea of steady states (Davoudi et al., 2013). Instead of seeing the world as something that is ordered, mechanical and reasonably predictable, this view sees the world as chaotic, complex, uncertain and unpredictable. Folke (2006) says that resilience is not just about being persistent or resistant to disturbance; rather it is also about the opportunities that disturbance opens up in terms of recombination of evolved structures and processes, renewal of the systems, and emergence of new trajectories. Carpenter et al. (2005) do not conceive of resilience as a return to a normal or stable situation, but as the ability of complex social-ecological systems to continuously change, adapt and transform in response to stresses and tensions.

The evolutionary view contrasts with earlier views on resilience. Resilience was once defined by Holling (1973) as the ability of a system to return to an equilibrium or steady state after a disturbance. The recovery time of the system to return to equilibrium was the measure of resilience, meaning that the faster the system would recover, the more resilient the system. This so-called engineering perspective on resilience focussed on the maintenance of the system's efficiency, its stability and assumes a predictable world (Folke, 2006).

It is not only the recovery time of a system that matters, but also the amount of disturbance that a system can withstand in order to stay within its thresholds. This is the basis for the ecological resilience approach, which focusses on the system's ability to persist and the ability to adapt (Adger et al., 2003). Both the engineering and ecological approaches to resilience start from the idea of the existence of equilibrium in systems. The main difference is that engineering resilience is based on a belief in a single and stable equilibrium, whereas ecological resilience rejects this and acknowledges the existence of multiple equilibria and the possibility the ability of a system to flip to alternate states.

Resilience thinking provides a way to understand human and natural systems as complex social-ecological systems that are continuously adapting (Strickland-Munro et al., 2010).

\section{Table I An overview of perspectives on resilience}

\begin{tabular}{|c|c|c|c|}
\hline Types & $\begin{array}{l}\text { Understanding of } \\
\text { equilibrium within type }\end{array}$ & $\begin{array}{l}\text { Characteristics } \\
\text { of the type }\end{array}$ & Key references \\
\hline Engineering resilience & One stable equilibrium & Bouncing back & Holling $(1973,1986)$ \\
\hline Ecological resilience & Multiple equilibria & Bouncing forth & Adger et al. (2003) \\
\hline $\begin{array}{l}\text { Evolutionary resilience } \\
\text { (social-ecological resilience) }\end{array}$ & Towards equilibrium & Adapt and transform & $\begin{array}{l}\text { Davoudi et al. (2012), } \\
\text { Folke et al. (2010) }\end{array}$ \\
\hline Source: Author & & & \\
\hline
\end{tabular}


Instead of being in equilibrium, the subsystems within the social-ecological system are constantly interacting with and responding to each other, but the system is also influenced by the external context. Figure 2 shows that the tourism-landscape system is impacted by external influences, and that each subsystem responds to this and to the impact on the other subsystem in an iterative way. This continuous process of impact and response between tourism and landscape is called co-evolutionary behaviour and leads to new behaviour of the entire system.

\subsection{A critical reflection on resilience}

Although the term resilience is widely used (Adger, 2000), there are many criticisms (Plieninger and Bieling, 2012; Fabinyi et al. , 2014). First, when translating the concept into the social sciences there are issues with the normativeness of the concept. Resilience implies a desired outcome, but some outcomes may be perceived as desirable for some, but not for others (Davoudi, 2012). Systems may be ecologically resilient, but socially undesirable, or the other way round. Second, resilience thinking can be improved by giving more attention to social diversity. Fabinyi et al. (2014) state that diverse and contested interests in social-ecological systems have received little attention. To understand how systems change and affect different people in different ways, it may help to consider resilience at different spatial and temporal scales. Third, resilience has been criticized for being one-sided, from multiple sides! Some argue that resilience is a socially constructed idea of landscape management to the detriment of biophysical perspectives, while others consider that resilience is too much in the hands of biophysical-ecology people (Kirchhoff et al., 2010). Fourth, Fabinyi et al. (2014) emphasize that resilience lacks attention to values and power. Within social-ecological systems, the understanding of different perspectives of different interest groups is important, but the notion of power relations can be improved. Power relations deal with the fact that some voices are heard, whilst others are marginalized or even silenced. A better understanding of the question "resilience for whom" (Lebel et al., 2006) could be achieved by not only looking at the outcomes, but also looking at the discursive dimension of power in social-ecological systems (Fabinyi et al. , 2014). The critique that resilience is power blind and that it depoliticizes the dynamics of change in social-ecological systems (Wilkinson, 2012) means that social-ecological resilience needs to further develop its theoretical sophistication and its capacity to address matters of power, conflict, contradiction and culture (Wilkinson, 2012). Fifth, planning and governance issues are context dependent and therefore resilience thinking does not offer a one-size-fits-all solution. Therefore, this paper strongly emphasizes that resilience thinking should not be seen as panacea (Ostrom and Cox, 2010; Walker et al., 2004). To address this panacea problem, comparative research is important because it can illuminate differences in the way tourism and landscape in coastal areas is managed. Looking at empirical cases from different international contexts could show best (and worst) practice on the management of tourism and landscape.

Figure 2 Co-evolutionary behaviour of the integrated tourism-landscape system

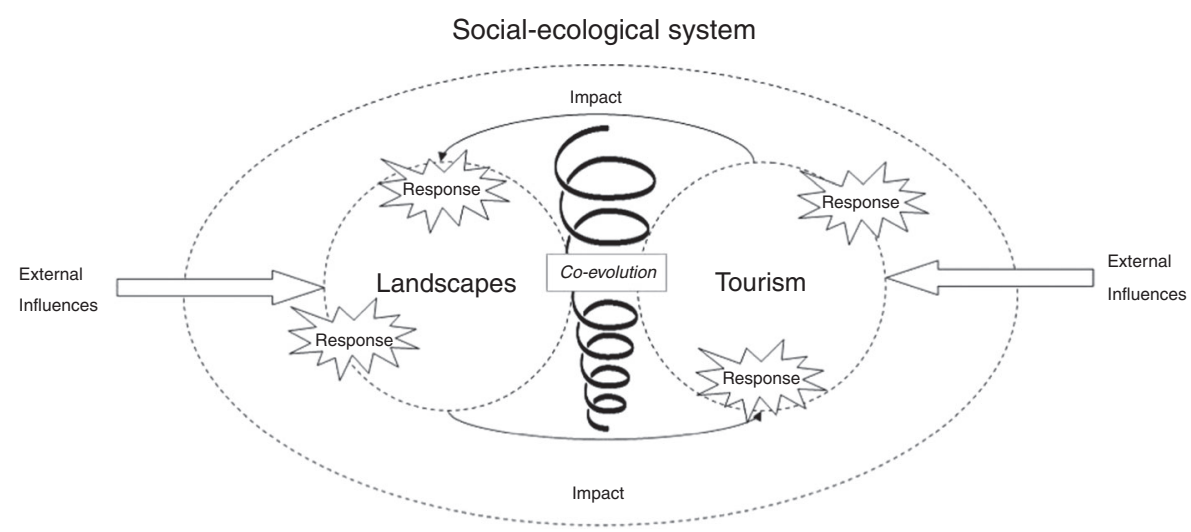

Source: Author 


\section{Governing tourism and landscape in coastal areas}

Davidson (2010) states that people consciously act, both individually and collectively, and that this human agency is what distinguishes social systems from ecological systems. For the management of tourism destinations to serve the goals of both nature conservation and socio-economic regional development, it is important to understand the way social-ecological systems are governed and the role institutions play (Bramwell and Lane, 2011). An implication of a social-ecological systems perspective for governance processes is that decision makers are encouraged to become less concerned with prediction and control, and to move towards more organic, flexible and adaptive management styles (Lister, 2008). This is because the governing and managing of a combined social and ecological system is a difficult task. Social and ecological systems have become increasingly interlinked, especially because of the increasing size of human populations, the increasing level of economic development, and the increasing interest in natural areas especially in coastal zones (Vanclay, 2012). This means that human influences on the environment are increasing.

A challenge for central government is that it is often limited in its ability to respond to rapid social-ecological changes and to cope with uncertainty (Armitage et al., 2009). Governance, however, is a concept (and a system) that includes more actors than only government. It is defined as "the complex system of regulation involving the interactions of a wide variety of actors, institutions, the environment and all types of socio-institutional arrangements at different territorial levels" (Parra, 2010, p. 491). Governance provides for a range of flexible social arrangements that are necessary to develop the rules, institutions and incentives to influence the management of tourism and landscapes in a complex and uncertain world (Armitage et al., 2009).

Another implication of a social-ecological systems perspective is an inclusive type of governance process, in which a multitude of stakeholders can be represented. Conflict may arise because stakeholders can have diverse interests for the use of nature areas (Mose, 2007). The social sciences have a specific responsibility to inform decision makers about the different roles people can have (Shultis and Way, 2006). The challenge is to make the integration of different interests possible (Mose, 2007).

Social-ecological systems imply a multi-scalar system (Adger et al., 2003; Brondizio et al., 2009; Folke et al., 2005). Insights into governance processes can help to show multi-scalar tensions between nature and society, because the dynamics of human-nature systems are influenced by many factors, including government policies and contextual factors. This means that local processes are shaped by larger-scale processes (Liu et al., 2007). Therefore, the effective management of nature areas is impossible without also having management strategies for the areas adjacent to the nature areas. In that sense, a multi-scalar approach highlights that institutional linkages are important.

Institutions are important in overcoming the traditional divide between social and natural systems, since they are the central component linking social and ecological resilience (Adger, 2000). To understand how planning issues regarding tourism and landscapes are managed, analysing the institutional arrangements regarding tourism in landscapes can be useful. Society's capacity to build resilience resides in the interactions among actors, social networks and institutions (Lebel et al., 2006). Institutions are defined here in the broadest sense to include informal behaviour and the rules and norms that govern society, as well as the formal institutions with memberships, constituencies and stakeholders (Adger, 2000). Institutions often form nested systems in which higher level institutions set limits to the procedures and alternatives that are available at lower levels (Adger et al., 2003).

\section{An application of the social-ecological systems perspective to the Dutch Wadden}

\subsection{Introduction to the Dutch Wadden}

To show the applicability of the social-ecological systems perspective to tourism and landscape, we demonstrate its application in the context of the Dutch Wadden. The greater Wadden region (or trilateral Wadden) stretches from the northwest of the Netherlands, along the German coast, 
and up the western part of Denmark. This paper only focusses on the Dutch part of the Wadden, which is shown in Figure 3. The area consists of three parts; the Wadden Sea itself, the coastal mainland area and the Wadden islands. The Wadden Sea is the largest unbroken system of intertidal sand and mudflats in the world and is of great ecological importance (UNESCO, 2009). The coastal mainland is that area adjacent to the Wadden Sea, where agriculture is traditionally the dominant function. However, tourism still plays a minor, although increasing role. In contrast, tourism plays a major role on the Wadden islands, as it is the primary source of employment (Kabat et al., 2009). In all these parts of the Wadden there are interactions between tourism and landscape, but in different ways and this requires different forms of management.

The Wadden sea is renowned for its outstanding ecological qualities and scenic landscape. Because of this, it was enlisted as natural heritage on the UNESCO World Heritage list in 2009. Plates 1 and 2 give an impression of the Wadden landscape. In these pictures, it is evident that despite the natural qualities of the area, the Wadden sea is not a remote ecosystem that has minimal human influence. Humans have been present in the area for around 10,000 years, since the last ice-age (Bazelmans et al., 2012; Knottnerus, 2005). Apart from being a nature area, the Wadden area is used for various socio-economic activities such as agriculture, fishing, human settlement, manufacturing, resource extraction, shipping and tourism (Kabat et al., 2012).

Tourism developed more recently than the other socio-economic activities in the Wadden, starting on the islands in a minor way about 100 years ago. After second world war, tourism steadily increased, becoming an important economic activity on the islands (Sijtsma et al., 2015; Postma, 2013). Its natural qualities made the Wadden very attractive to tourists (Revier, 2013; Sijtsma et al., 2012). Although the Dutch Wadden is only about one third of the total area of the Trilateral Wadden, its economic importance is much greater. For example, 6.5 million tourist nights are spent in the Dutch Wadden each year. Specifically, some 5.1 million nights are spent on the Dutch islands by 1.2 million people (Sijtsma et al., 2012).

Tourism opportunities in the area and its UNESCO recognition contribute to the increasing amount of tourism activities, but also emphasizes the responsibility to take care of the outstanding natural and cultural values which attract these tourists. Proper management of this

\section{Figure 3 The Dutch Wadden}

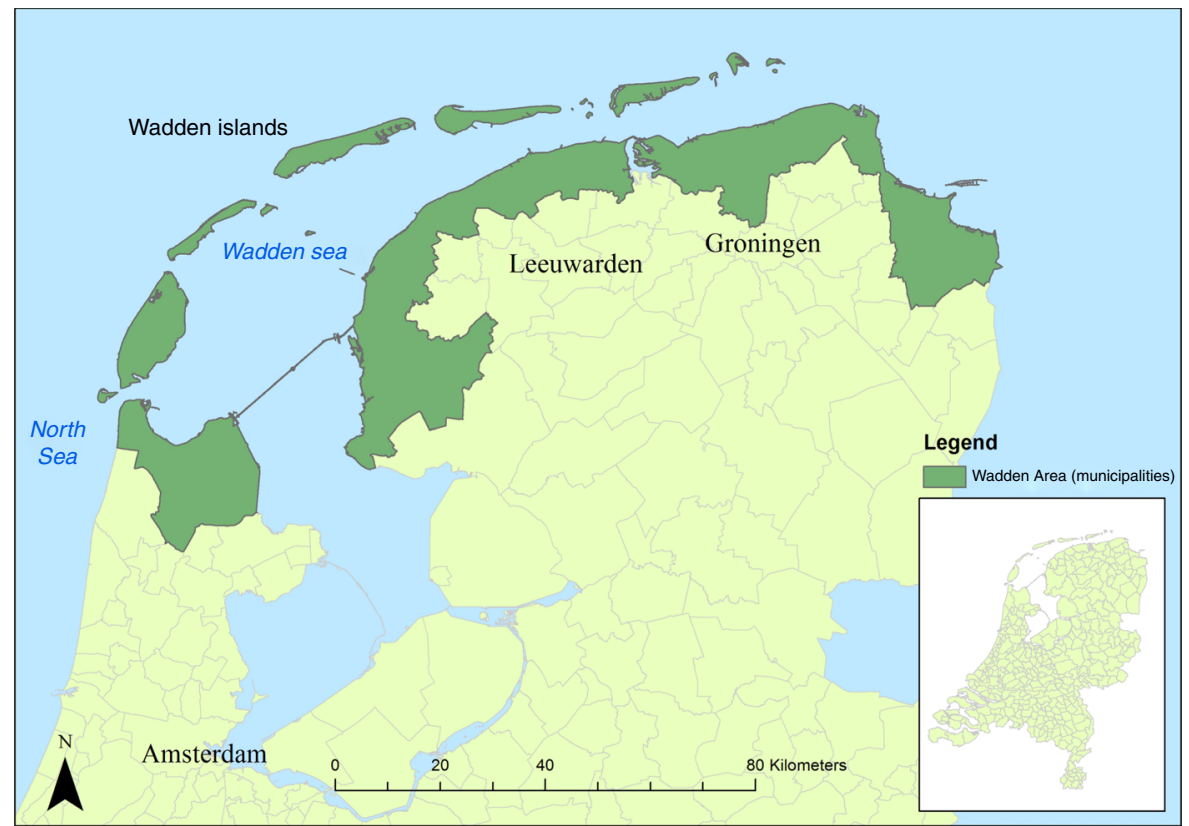

Source: BBG (2010), adapted by author in GIS 




Plate 2 Tidal flat area

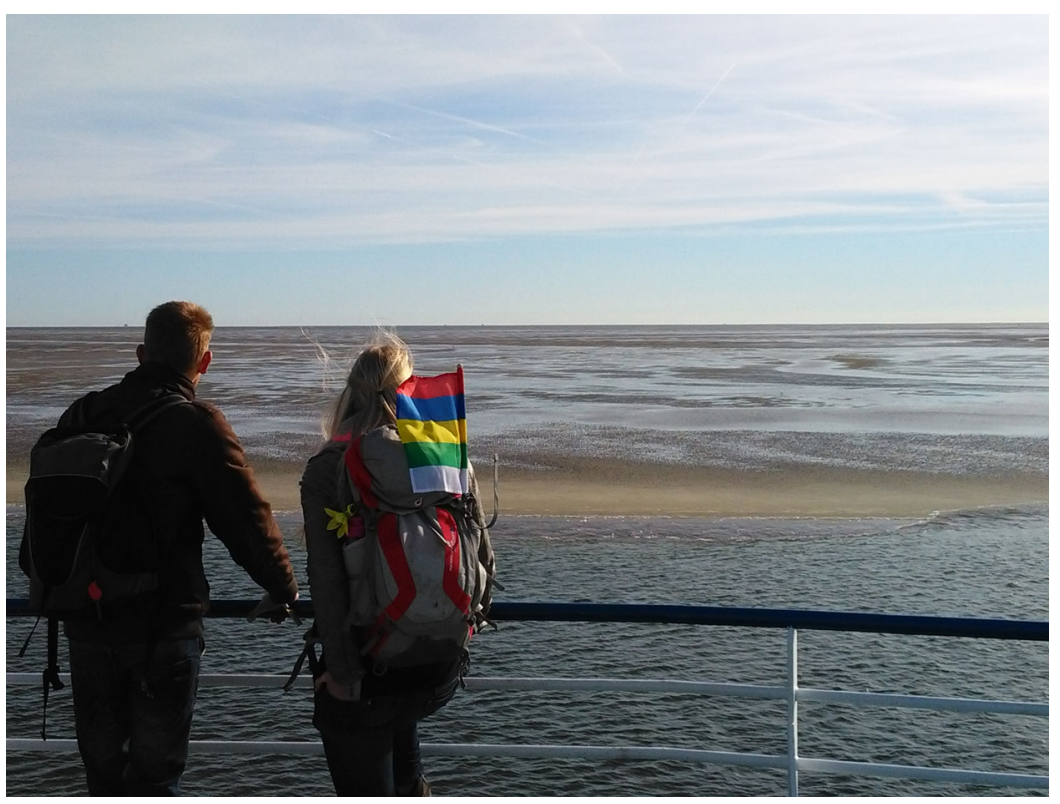

Source: Author (2015)

area is necessary. This means it is important to have clear rules and regulations to mitigate the human impacts in the area, and also that opportunities for socio-economic development be provided. Since the 1970s the Wadden area has been managed with many rules and regulations along multiple scales and "Hands off the Wadden sea" became the dominant discourse (Runhaar, 2009). However, a strong emphasis on nature protection may hinder socio-economic 
opportunities that allow for synergies with the landscape. Finding the proper balance between nature protection and allowing opportunities for socio-economic development is difficult and is under constant discussion.

\subsection{The Wadden as a coupled social-ecological system}

If the Wadden area is to be examined from a social-ecological systems perspective, this requires that this area be framed as an integrated and coupled system. This would allow previously ignored synergies between tourism and landscape to be identified and understood. For example, past and contemporary planning strategies for rural areas in the Netherlands have mainly focussed on two dominant forms of land use: agriculture and nature (Hartman and de Roo, 2009). Tourism and leisure fell outside these traditional land use functions, and this limited (and continues to limit) the possibilities for synergies between tourism and landscape (Hartman and de Roo, 2009). This is especially the situation for the mainland part of the Wadden. Being adjacent to the UNESCO World Heritage site, this area has enormous potential for synergies between tourism and landscape, because here synergies are relatively unexploited, as tourism is still in its infancy and agriculture remains the dominant type of land use. In contrast, the Wadden islands show a different story - due to the attractive landscape, tourism has already developed into an established industry and tourism has a large impact on the landscape and the community. The challenge to find synergies on the islands is to look for development paths in such a way that tourism may serve the needs of both nature protection and socio-economic development. Together, the Wadden shows that, in both situations (underdevelopment on the mainland, and overpressure on the islands), a social-ecological systems perspective is useful. It frames tourism and landscape in coastal areas as part of an integrated and coupled system and therefore this perspective can help to understand the complex interactions between tourism and landscape.

\subsection{Resilience as a dynamic perspective to overcome the challenges for the Wadden}

Resilience thinking is a dynamic perspective that takes change and uncertainty into account and can be helpful in understanding how to cope with ecological, social and economic changes. According to Folke (2003), change has the potential to create opportunity for development, novelty and innovation, and to keep the system resilient. During the coming decades, the Wadden area will be increasingly challenged as it faces increasing ecological, social and economic changes. Kabat et al. (2012) consider the ecological state of the Wadden to be fragile and vulnerable to external and internal disturbance (e.g. global warming, sea-level rise, globalization of biota, diseases, economic exploitation). The socio-economic situation of the area is also fragile. Although, the area is highly attractive to visitors, the region is facing population decline, a reduction in economic activity, and consequential loss of social cohesion (van Dijk et al., 2009). Because of its fragile economic structure, utilizing opportunities for tourism and recreation development is of great importance for the economic development of the region, and also to strengthen the region's liveability (van Dijk et al., 2009). Given these challenges, it can be said that the Wadden is an area which is dynamic in both social and ecological terms, and the situation in the Wadden is not stable or completely predictable. This means that, for example, the strict regulation of nature protection on the Wadden islands can lead to problems in adapting to these constantly changing circumstances. Managing the Wadden in a static way with a strong focus on nature protection reflects the criticism on resilience explained in this paper. Although this paper argues that resilience is a useful concept as it helps to constantly seek a balance between the needs for nature protection and socio-economic development, resilience thinking needs to take social components into account such as cultural values, diversity, inclusiveness and power.

\subsection{Governing for social-ecological resilience in the Wadden}

Resilience thinking about multi-functional social-ecological systems has implications for governance processes, which need to be more flexible, inclusive and multilevel. However, these theoretical implications can be difficult to implement in practice, because the way the Wadden is managed has become difficult. The governance of the Wadden can be characterized 
as a complex, layered, varied and - in the eyes of many - highly fragmented administrative and managerial organization (Toonen, 2009; Giebels et al., 2013). The complexity of the governance of such multi-functional areas is apparent (Toonen, 2009), because many organizations with sometimes conflicting interests are involved in the management of the area (van Dijk et al. , 2009). Conflicts between stakeholders may hinder opportunities for finding synergies between tourism and landscape. For example, conflicts among tourism entrepreneurs and nature protection interest groups may create suboptimal outcomes for both the social and ecological systems. This raises questions about how these difficulties can be overcome. Questions regarding who are involved in the process, who are excluded, what are the varying interests, and to what extent can the governance process be improved, will help increase the understanding of tourism in coastal areas.

\section{Conclusion}

This paper argued for the use of a social-ecological systems perspective to understand the complex interactions between tourism and landscape in coastal areas. This perspective can help reveal the potential of tourism to build social-ecological resilience. The social-ecological systems perspective is likely to illuminate missed opportunities for synergies between tourism and landscapes. By means of the example of the Dutch Wadden, we illustrated that, although coastal areas are facing several ecological, social and economic challenges, tourism can help to protect nature areas, while at the same time allowing for socio-economic regional development.

This paper proposed a different understanding of tourism by approaching both tourism and nature areas in a more integrated and multi-functional way. The social-ecological systems approach argues that the social system and the natural system form an integrated whole. How the subsystems co-evolve can be understood by looking at their interactions and feedbacks. For understanding the current situation and possible future directions, it is important to know the evolution of tourism and landscapes. Whether synergies between tourism and landscapes are found in the current situation or not is partly a result of historical events, however, a new way of looking at the issue - i.e. from a social-ecological systems perspective - is likely to reveal possibilities that were previously hidden.

A social-ecological systems perspective deals with change and uncertainty in a more sophisticated way than thinking about a system only in terms of stability and certainty. This paper suggests that resilience thinking improves how systems are managed. This has implications for the governance of tourism in coastal areas. Essentially, governance needs to be more flexible, more inclusive, and multilevel. We advocate that landscape managers should adopt a social-ecological systems perspective to help them identify new opportunities for meeting the varied objectives of the multiple components of their landscape system.

\section{References}

Adger, W.N. (2000), "Social and ecological resilience: are they related?", Progress in Human Geography, Vol. 24 No. 3, pp. 347-64.

Adger, W.N., Hughes, T.P., Folke, C., Carpenter, S.R. and Rockström, J. (2005), "Social-ecological resilience to coastal disasters", Science, Vol. 309 No. 5737, pp. 1036-9.

Adger, W.N., Brown, K., Fairbrass, J., Jordan, A., Paavola, J., Rosendo, S. and Seyfang, G. (2003), "Governance for sustainability: towards a 'thick' analysis of environmental decisionmaking", Environment and Planning A, Vol. 35 No. 6, pp. 1095-110.

Amérigo, M., Aragonés, J.I., de Frutos, B., Sevillano, V. and Cortés, B. (2007), "Underlying dimensions of ecocentric and anthropocentric environmental beliefs", The Spanish Journal of Psychology, Vol. 10 No. 1, pp. 97-103.

Armitage, D.R., Plummer, R., Berkes, F., Arthur, R.I., Charles, A.T., Davidson-Hunt, I.J., Diduck, A.P., Doubleday, N.C., Johnson, D.S., Marschke, M., McConney, P., Pinkerton, E.W. and Wollenberg, E.K. (2009), "Adaptive co-management for social-ecological complexity", Frontiers in Ecology and the Environment, Vol. 7 No. 2, pp. 95-102. 
Bazelmans, J., Meier, D., Nieuwhof, A., Spek, T. and Vos, P. (2012), “Understanding the cultural historical value of the Wadden Sea region. The co-evolution of environment and society in the Wadden Sea area in the Holocene up until early modern times (11,700 BC-1800 AD): an outline", Ocean and Coastal Management, Vol. 68 No. 2012, pp. 114-26.

BBG (2010), “CBS Bestand Bodemgebruik 2010", available at: https://geodata.nationaalgeoregister.nl/ bestandbodemgebruik2010/wms?request=GetCapabilities

Becken, S. (2013), "Developing a framework for assessing resilience of tourism sub-systems to climatic factors", Annals of Tourism Research, Vol. 43 No. 2013, pp. 506-28.

Berkes, F. (2007), "Understanding uncertainty and reducing vulnerability: lessons from resilience thinking", Natural Hazards, Vol. 41 No. 2, pp. 283-95.

Berkes, F., Colding, J. and Folke, C. (2003), "Introduction”, in Berkes, F., Colding, J. and Folke, C. (Eds), Navigating Social-Ecological Systems: Building Resilience for Complexity and Change, Cambridge University Press, Cambridge, pp. 1-29.

Binder, C.C.R., Hinkel, J., Bots, P.W.G. and Pahl-Wostl, C. (2013), "Comparison of frameworks for analyzing social-ecological systems”, Ecology and Society, Vol. 18 No. 4, available at: http://dx.doi.org/10.5751/ES05551-180426Research

Bramwell, B. and Lane, B. (2011), "Critical research on the governance of tourism and sustainability", Journal of Sustainable Tourism, Vol. 19 Nos 4-5, pp. 411-21.

Brondizio, E.S., Ostrom, E. and Young, O.R. (2009), "Connectivity and the governance of multilevel socialecological systems: the role of social capital", Annual Review of Environment and Resources, Vol. 34 No. 1, pp. 253-78.

Buckley, R. (2011), "Tourism and environment”, Annual Review of Environment and Resources, Vol. 36 No. 1, pp. 397-416.

Buckley, R. (2012), "Sustainable tourism: research and reality", Annals of Tourism Research, Vol. 39 No. 2, pp. 528-46.

Carpenter, S., Walker, B., Anderies, J.M. and Abel, N. (2001), "From metaphor to measurement: resilience of what to what?", Ecosystems, Vol. 4 No. 8, pp. 765-81.

Carpenter, S.R., Westley, F. and Turner, G. (2005), "Surrogates for resilience of social-ecological systems", Ecosystems, Vol. 8 No. 8, pp. 941-4.

Costanza, R. and Farley, J. (2007), "Ecological economics of coastal disasters: introduction to the special issue", Ecological Economics, Vol. 63 Nos 2-3, pp. 249-53.

Cox, R.S. and Perry, K.M. (2011), "Like a fish out of water: reconsidering disaster recovery and the role of place and social capital in community disaster resilience", American Journal of Community Psychology, Vol. 48 Nos 3-4, pp. 395-411.

Cumming, G., Allen, C. and Ban, N. (2015), "Understanding protected area resilience: a multi-scale, social-ecological approach”, Ecological Applications, Vol. 25 No. 2, pp. 299-319.

Cumming, G.S. (2011a), Spatial Resilience in Social-Ecological Systems, Springer, Dordrecht.

Cumming, G.S. (2011b), "Spatial resilience: integrating landscape ecology, resilience, and sustainability", Landscape Ecology, Vol. 26 No. 7, pp. 899-909.

Davidson, D.J. (2010), "The applicability of the concept of resilience to social systems: some sources of optimism and nagging doubts”, Society \& Natural Resources, Vol. 23 No. 12, pp. 1135-49.

Davoudi, S. (2012), "Resilience: a bridging concept or a dead end?", Planning Theory \& Practice, Vol. 13 No. 2, pp. 299-307.

Davoudi, S., Brooks, E. and Mehmood, A. (2013), "Evolutionary resilience and strategies for climate adaptation", Planning Practice \& Research, Vol. 28 No. 3, pp. 307-22.

Davoudi, S., Shaw, K., Haider, L.J., Quinlan, A.E., Peterson, G.D., Wilkinson, C. and Porter, L. (2012), "Resilience: a bridging concept or a dead end? 'reframing' resilience: challenges for planning theory and practice interacting traps: resilience assessment of a pasture management system in northern Afghanistan urban resilience: what does it mean in planning", Planning Theory \& Practice, Vol. 13 No. 2, pp. 299-333. 
Fabinyi, M., Evans, L. and Foale, S. (2014), "Social-ecological systems, social diversity, and power: insights from anthropology and political ecology”, Ecology and Society, Vol. 19 No. 4, available at: http://dx.doi.org/ 10.5751/ES-07029-190428

Farrell, B.H. and Twining-Ward, L. (2004), "Reconceptualizing tourism", Annals of Tourism Research, Vol. 31 No. 2, pp. 274-95.

Folke, C. (2003), "Social-ecological resilience and behavioural responses", in Biel, A., Hansson, B. and Martensson, M. (Eds), Individual and Structural Determinants of Environmental Practice, Ashgate Publishers, London, pp. 226-87.

Folke, C. (2006), "Resilience: the emergence of a perspective for social-ecological systems analyses", Global Environmental Change, Vol. 16 No. 3, pp. 253-67.

Folke, C., Hahn, T., Olsson, P. and Norberg, J. (2005), "Adaptive governance of social-ecological systems", Annual Review of Environment and Resources, Vol. 30 No. 1, pp. 441-73.

Folke, C., Carpenter, S.R., Walker, B., Scheffer, M., Chapin, T. and Rockstrom, J. (2010), "Resilience thinking: integrating resilience, adaptability and transformability", Ecology and Society, Vol. 15 No. 4, available at: www. ecologyandsociety.org/ vol15/iss4/art20/

Giebels, D., van Buuren, A. and Edelenbos, J. (2013), "Ecosystem-based management in the Wadden Sea: principles for the governance of knowledge", Journal of Sea Research, Vol. 82 No. 2013, pp. 176-87.

Gkoltsiou, A. and Terkenli, T.S. (2012), "An interdisciplinary analysis of tourist landscape structure", Tourismos, Vol. 7 No. 2, pp. 145-64.

Goodwin, H. (2011), Taking Responsibility for Tourism, Goodfellow, Oxford.

Gunderson, L.H., Carpenter, S.R., Folke, C., Olsson, P. and Peterson, G. (2006), "Water RATs (resilience, adaptability, and transformability) in Lake and Wetland social-ecological systems", Ecology and Society, Vol. 11 No. 1, available at: www.ecologyandsociety.org /vol11/iss1/art16/

Hall, C.M. and Page, S. (2006), The Geography of Tourism and Recreation: Environment, Place and Space, Psychology Press, Oxford.

Halliday, A. and Glaser, M. (2011), "A management perspective on social ecological systems : a generic system model and its application to a case study from Peru", Human Ecology, Vol. 18 No. 1, pp. 1-18.

Hartman, S. and de Roo, G. (2009), Op het snijvlak van risico en kansen, KNAW-Waddenacademie, Leeuwarden.

Hartman, S., Rauws, W.S., Beeftink, M.J., De Roo, G., Zandbelt, D., Frijters, E. and Klijn, O. (2011), "De ontwikkeling van regioconcepten-developing regional spatial concepts", in Ovink, H. and Wierenga, E. (Eds), Regio's in verandering; ontwerpen voor adaptiviteit-regions in transition; designing for adaptivity, 010 Publishers, Rotterdam, pp. 36-61.

Higgins-Desbiolles, F. (2006), "'More than an industry': the forgotten power of tourism as a social force", Tourism Management, Vol. 27 No. 6, pp. 1192-208.

Holling, C.S. (1973), "Resilience and stability of ecological systems", Annual Review of Ecological Systems, Vol. 4 No. 1973, pp. 1-23.

Holling, C.S. (1986), "Resilience of ecosystems; local surprise global change", in Clark, W.C. and Munn, R.E. (Eds), Sustainable Development of the Biosphere, Cambridge University Press, Cambridge, pp. 292-317.

Holling, C.S. (2000), "Understanding the complexity of economic, ecological, and social systems", Ecosystems, Vol. 4 No. 5, pp. 390-405.

Kabat, P., Bazelmans, J., van Dijk, J., Herman, P.M.J., Speelman, H., Deen, N.R.J. and Hutjes, R.W.A. (2009), Kennis Voor Een Duurzame Toekomst van de Wadden, KNAW-Waddenacademie, Leeuwarden.

Kabat, P., Bazelmans, J., van Dijk, J., Herman, P.M.J., van Oijen, T., Pejrup, M., Reise, K. et al. (2012), "The Wadden Sea Region: towards a science for sustainable development”, Ocean \& Coastal Management, Vol. 68 No. 2012, pp. 4-17.

King, B., Pizam, A. and Milman, A. (1993), "Social impacts of tourism: host perceptions", Annals of Tourism Research, Vol. 20 No. 1993, pp. 650-65.

Kirchhoff, T., Brand, F.S., Hoheisel, D. and Grimm, V. (2010), "The one-sidedness and cultural bias of the resilience approach", Gaia, Vol. 19 No. 1, pp. 25-31. 
Knottnerus, O.S. (2005), "History of human settlement, cultural change and interference with the marine environment”, Helgoland Marine Research, Vol. 59 No. 1, pp. 2-8.

Lebel, L., Anderies, J.M., Campbell, B., Folke, C., Hatfield-Dodds, S., Hughes, T.P. and Wilson, J. (2006), "Governance and the capacity to manage resilience in regional social-ecological systems", Ecology and Society, Vol. 11 No. 1, available at: www.ecologyandsociety.org/ vol11/iss1/art19/Insight

Levin, S., Xepapadeas, T., Crépin, A.-S., Norberg, J., de Zeeuw, A., Folke, C., Hughes, T., Arrow, K., Barrett, S., Daily, G., Ehrlich, P., Kautsky, N., Mäler, K.-G., Polasky, S., Troell, M., Vincent, J.R. and Walker, B. (2012), "Social-ecological systems as complex adaptive systems: modeling and policy implications", Environment and Development Economics, Vol. 18 No. 2, pp. 111-32.

Libosada, C.M. (2009), "Business or leisure? Economic development and resource protection-concepts and practices in sustainable ecotourism", Ocean and Coastal Management, Vol. 52 No. 7, pp. 390-4.

Lister, N.-M.E. (2008), "Bridging science and values: the challenge of biodiversity conservation", in Waltner-Toews, D., Kay, J. and Lister, N.-M.E. (Eds), The Ecosystem Approach: Complexity, Uncertainty, and Managing for Sustainability, Columbia University Press, New York, NY, pp. 83-108.

Liu, J., Dietz, T., Carpenter, S.R., Alberti, M., Folke, C., Moran, E., Pell, A.N., Deadman, P., Kratz, T., Lubchenco, J., Ostrom, E., Ouyang, Z., Provencher, W., Redman, C.L., Schneider, S.H. and Taylor, W.W. (2007), "Complexity of coupled human and natural systems", Science, Vol. 317 No. 5844, pp. 1513-6.

Luthe, T. and Wyss, R. (2014), "Assessing and planning resilience in tourism", Tourism Management, Vol. 44, pp. 161-3.

McCombes, L., Vanclay, F. and Evers, Y. (2015), "Putting social impact assessment to the test as a method for implementing responsible tourism practice”, Environmental Impact Assessment Review, Vol. 55 No. 2015, pp. 156-68.

McCool, S.F. and Spenceley, A. (2014), "Tourism and protected areas: a growing nexus of challenge and opportunity”, Koedoe, Vol. 56 No. 2, pp. 1-2.

Millennium Ecosystems Assessment (2005), Ecosystems and Human Well-Being: Scenarios, Island Press, Washington, DC.

Mose, I. (Ed.) (2007), Protected Areas and Regional Development in Europe: Towards a New Model for the 21th Century, Ashgate, Aldershot.

Newsome, D., Moore, S.A. and Dowling, R.K. (2013), Natural Area Tourism: Ecology, Impacts and Management, 2nd ed., Channel View Publications, Bristol.

Ostrom, E. and Cox, M. (2010), "Moving beyond panaceas: a multi-tiered diagnostic approach for social-ecological analysis", Environmental Conservation, Vol. 37 No. 4, pp. 451-63.

Parra, C. (2010), "Sustainability and multi-level governance of territories classified as protected areas in France: the Morvan regional park case”, Journal of Environmental Planning and Management, Vol. 53 No. 4, pp. 491-509.

Persha, L., Agrawal, A. and Chhatre, A. (2011), "Social and ecological synergy", Science, Vol. 331 No. 6024, pp. 1606-8.

Plieninger, T. and Bieling, C. (2012), Resilience and the Cultural Landscape - Understanding and Managing Change in Human-Shaped Environments, Cambridge University Press, Cambridge.

Plummer, R. and Armitage, D. (2007), "A resilience-based framework for evaluating adaptive co-management: linking ecology, economics and society in a complex world", Ecological Economics, Vol. 61 No. 1, pp. 62-74.

Plummer, R. and Fennell, D.A. (2009), "Managing protected areas for sustainable tourism: prospects for adaptive co-management", Journal of Sustainable Tourism, Vol. 17 No. 2, pp. 149-68.

Postma, A. (2013), When the Tourists Flew in: Critical Encounters in the Development of Tourism, University of Groningen, Groningen.

Revier, H. (2013), "Nature conservation and tourism development in the Dutch Wadden Sea region: a common future?", in Postma, A., Yeoman, I. and Oskam, J. (Eds), The Future of European Tourism, European Tourism Futures Institute, Leeuwarden, pp. 177-93. 
Robertson, M. (2012), "Measurement and alienation: making a world of ecosystem services", Transactions of the Institute of British Geographers, Vol. 37 No. 3, pp. 386-401.

Ruiz-Ballesteros, E. (2011), "Social-ecological resilience and community-based tourism: an approach from Agua Blanca, Ecuador", Tourism Management, Vol. 32 No. 3, pp. 655-66.

Runhaar, H. (2009), "Putting SEA in context: a discourse perspective on how SEA contributes to decision-making", Environmental Impact Assessment Review, Vol. 29 No. 3, pp. 200-9.

Saarinen, J. (2006), "Traditions of sustainability in tourism studies”, Annals of Tourism Research, Vol. 33 No. 4 , pp. 1121-40.

Schianetz, K. and Kavanagh, L. (2008), "Sustainability indicators for tourism destinations: a complex adaptive systems approach using systemic indicator systems", Journal of Sustainable Tourism, Vol. 16 No. 6, pp. 601-28.

Schroter, M., van der Zanden, E.H., van Oudenhoven, A.P.E., Remme, R.P., Serna-Chavez, H.M., de Groot, R.S. and Opdam, P. (2014), "Ecosystem services as a contested concept: a synthesis of critique and counter-arguments", Conservation Letters, Vol. 7 No. 6, pp. 514-23.

Shipman, B. and Stojanovic, T. (2007), "Facts, fictions, and failures of integrated coastal zone management in Europe", Coastal Management, Vol. 35 Nos 2-3, pp. 375-98.

Shultis, J.D. and Way, P.A. (2006), "Changing conceptions of protected areas and conservation: linking conservation, ecological integrity and tourism management", Journal of Sustainable Tourism, Vol. 14 No. 3, pp. 37-41.

Sijtsma, F.J., Daams, M.N., Farjon, H. and Buijs, A.E. (2012), "Deep feelings around a shallow coast: a spatial analysis of tourism jobs and the attractivity of nature in the Dutch Wadden area", Ocean \& Coastal Management, Vol. 68 No. 2012, pp. 138-48.

Sijtsma, F.J., Broersma, L., Daams, M.N., Hoekstra, H. and Werner, G. (2015), "Tourism development in the Dutch Wadden area: spatial-temporal characteristics and monitoring needs", Environmental Management and Sustainable Development, Vol. 4 No. 2, pp. 217-41.

Stoffelen, A. and Vanneste, D. (2015), "An integrative geotourism approach: bridging conflicts in tourism landscape research", Tourism Geographies, Vol. 17 No. 4, pp. 1-17.

Strickland-Munro, J.K., Allison, H.E. and Moore, S.A. (2010), "Using resilience concepts to investigate the impacts of protected area tourism on communities", Annals of Tourism Research, Vol. 37 No. 2, pp. 499-519.

Terkenli, T.S. (2004), "Tourism and landscape", in Lew, A.A., Hall, C.M. and Williams, A.M. (Eds), A Companion to Tourism, Blackwell, Oxford, pp. 339-48.

Toonen, T.A.J. (2009), "Good governance for the Wadden: the organisation of decision-making for sustainability", paper for presentation at Workshop 4 (WOW4), Workshop in Political Theory and Policy Analysis, Indiana University, Bloomington, IN.

UNESCO (2009), Wadden Sea, UNESCO, Seville, available at: http://whc.unesco.org/en/decisions/1946 (accessed 25 March 2016).

UNWTO (2010), Tourism 2020 Vision, UNESCO, World Tourism Organization, Madrid, available at: http://cf. cdn.unwto.org/sites/all/files/pdf/final_annual_report_pdf_3.pdf (accessed 25 March 2016).

van Dijk, J., Folmer, H., Broersma, L., van der Heide, M., Heijman, W., Horlings, I., Ivanova, O., Jonkhoff, W., Koops, O., Sijtsma, F. and van der Veen, A. (2009), Analyse van Problemen in Het Waddengebied, KNAW-Waddenacademie, Leeuwarden.

Vanclay, F. (2012), "The potential application of social impact assessment in integrated coastal zone management", Ocean \& Coastal Management, Vol. 68 No. 2012, pp. 149-56.

Walker, B., Holling, C.S., Carpenter, S.R. and Kinzig, A. (2004), "Resilience, adaptability and transformability in social-ecological systems", Ecology and Society, Vol. 9 No. 2, available at: www.ecologyandsociety.org/ vol9/iss2/art5

Wilkinson, C. (2012), "Social-ecological resilience: insights and issues for planning theory", Planning Theory, Vol. 11 No. 2, pp. 148-69.

Williams, S. (2009), Tourism Geography: A New Synthesis, Routledge, Abingdon. 


\section{Further reading}

Derissen, S., Quaas, M.F. and Baumgartner, S. (2011), "The relationship between resilience and sustainability of ecological-economic systems”, Ecological Economics, Vol. 70 No. 6, pp. 1121-8.

Holling, C.S. (2008), "Theories for sustainable futures", Conservation Ecology, Vol. 4 No. 2, pp. 5-9.

Ostrom, E. (2011), "Background on the institutional analysis and development", Policy Studies Journal, Vol. 39 No. 1, pp. 7-27.

\section{Corresponding author}

Jasper Hessel Heslinga can be contacted at: j.h.heslinga@rug.nl

For instructions on how to order reprints of this article, please visit our website: www.emeraldgrouppublishing.com/licensing/reprints.htm

Or contact us for further details: permissions@emeraldinsight.com 